\title{
THIRD-PARTY BENEFICIARIES AND CONTRACTUAL NETWORKS
}

\author{
Alan Schwartz* and Robert E. Scott**
}

\begin{abstract}
An increasing trend of economic agents is to form productive associations such as networks, platforms, and other hybrids. Subsets of these agents contract with each other to further their network project and these contracts can create benefits for, or impose costs on, agents who are not contract parties. Contract law regulates third party claims against contract parties with the third-party beneficiary doctrine, which directs courts to ask whether the contracting parties "intended" to benefit a particular third party. We show here what courts do with third party claims when network members fail to perform for third parties and what the law's best responses to such breaches should be. Among our principal results are that courts honor third party claims when contract members likely can price them and when third parties incur substantial reliance losses, but protect thirdparty interests less frequently than they should and refuse relief when contract members can identify the potential beneficiary class but not every agent who is likely to be in it.
\end{abstract}

\section{INTRODUCTION}

A recent and increasing trend of economic agents is to form productive associations such as networks, platforms, and other hybrids. ${ }^{1}$ A distinguishing feature of these associations is that they create a particular form of spillover. The typical contract is dyadic: it has two parties. Associations-referred to generically here as "networks" - have $\mathrm{N}>2$ members, but the members seldom write "master contracts" that everyone signs. Rather, subsets of members contract

* Sterling Professor of Law, Yale Law School; Professor, Yale School of Management.

** Alfred McCormack Professor of Law and Director, Center for Contract and Economic Organization, Columbia University email: rscott@law.columbia.edu. We are grateful for comments from Ronald Gilson, Victor Goldberg, Henry Hansmann, Tracy Lewis, Bentley McCloud, Jonathan Morgan, three anonymous referees and the participants at a Contract Theory Conference at Oxford, England, September 2014. Dane Thorley provided excellent research assistance.

1 Much current economic analysis of networks involves individual behavior. The analyst's goal is to understand such issues as the effectiveness of a micro-finance project or how a vaccination campaign would function. A good review is Jackson (2014). Because our concern is business behavior, we do not use this literature.

(C) The Author 2015. Published by Oxford University Press on behalf of The John M. Olin Center for Law, Economics and Business at Harvard Law School.

This is an Open Access article distributed under the terms of the Creative Commons Attribution Non-Commercial License (http://creativecommons.org/licenses/by-nc/4.0/), which permits non-commercial re-use, distribution, and reproduction in any medium, provided the original work is properly cited. For commercial re-use, please contact journals.permissions@oup.com doi:10.1093/jla/lav006 
with each other or create framework agreements that they and later parties join. These agreements may create benefits for, or impose costs on, agents that are not parties. For example, consider a set of banks, merchants, and consumers. Typically, Bank $B_{1}$ enters into an agreement with merchant $M$ that $B_{1}$ and other banks in $B_{1}$ 's group will process credit card payments that consumers make to $\mathrm{M}$, and, in turn, $\mathrm{M}$ agrees to take certain precautions to reduce the likelihood of fraud or unauthorized use. By taking these precautions, $M$ will increase the payoffs of group member banks $B_{2}$ and $B_{3}$, but their payoffs will decrease if the precautions are not taken. Neither bank $B_{2}$ nor bank $B_{3}$ contracts directly with $\mathrm{M}$, however.

The legal concerns that occupy us begin with the two facts just noted: transaction costs commonly preclude creating master contracts; and network agreements can create externalities. To be sure, dyadic contracts create externalities as well. A bank that writes improvident mortgage contracts imposes costs on people who deal with the mortgagor and on society at large. The definitional difficulty, therefore, is to know when affected non-parties are in or outside the relevant network. At first blush, observers probably would not put the mortgagor's neighbor in the same network as the mortgagor, though the value of the neighbor's house would fall if the mortgagor defaulted. On the other hand, the retail merchant and the three banks described above plainly seem in a network with each other.

We approach the definitional question functionally. Parties that contract with each other-the merchant and Bank $B_{1}$ in the example above-we refer to below as "contract members". Affected non-parties are in the relevant network - they are "beneficiary members"-if there is a good reason to include them. A good reason should derive from what we believe is the appropriate state goal: to facilitate the founding and performance of efficient networks. Notwithstanding the significance of this larger normative question, in this article we are concerned with two narrower but related legal questions: when can (and should) a third party be able to hold a contract member liable either for benefits the third party did not receive or costs it incurred? Thus, we are pursuing only a part of the broader question of how the state should facilitate the founding and performance of efficient networks. Because we ask this question through the lens of contract law, we are only looking at a small part of that question.

We approach the legal question by asking just when the goals of contract members would be materially furthered by the participation of particular third parties, or classes of third parties. Our more precise normative claim is that a court should find for a potential beneficiary member if contract member goals would be furthered by the participation of third parties in the class to which the plaintiff belongs. This claim rests on two premises. First, ex ante, contract 
members want the law to accord third-party beneficiary status to members of the plaintiff's class when and because their participation would increase the contract members' expected payoffs. In many network contexts the payoffs of members are increasing, over a range, in the population that consumes network services. As an illustration, insurance companies sometimes contract with hospitals to have the hospitals serve the companies' insureds. The payoffs of these contract members are increasing in the number of insureds that there are. Hence, an insured whom a hospital refuses to serve is a good candidate for beneficiary member status. Our second premise is that there is a positive, though imperfect, correlation between network welfare and social welfare. ${ }^{2}$ The practical implication of this premise is that when the criterion of network welfare would lead to a denial of beneficiary member status, a potential beneficiary member has the burden of showing that the denial would be inefficient all things considered.

In Section II we introduce the relevant contract law. Current doctrine directs courts to ask whether the relevant contract evidences an "intention" on the part of the contract parties to "confer a benefit" on the third-party plaintiff. The courts' question and ours are related: network members who would benefit from third party participation want to benefit these parties in order to induce them to participate. The cases sometimes deviate from the results our criterion implies, however, because when party intent is not obvious courts do not ask how a case outcome would advance or retard the particular network's economic goals. This, we show, can lead a court to deny third-party beneficiary status when application of our economic criterion would imply granting it. Hence, our analysis has normative implications.

Section III illustrates some actual networks that feature in litigation. In particular, this section argues that, broadly speaking, contract members benefit from the participation of third parties in two ways. First, as noted above, contract members benefit when their payoffs are increasing in the number of third parties that join the network either as suppliers, consumers or co-venturers in the common enterprise. Second, contract members benefit when third party participation would assist the members in creating a particular product-a piece of software or a new drug-or in creating standards that products should meet.

2 Because the correlation between network welfare and social welfare is imperfect, our normative views are tentatively held. An additional justification for adopting network welfare as a criterion is that normative critique, when directed at courts, should take into account the type of goal a court can implement. Courts are not equipped to make global welfare assessments, but should be able to discern whether permitting or denying a third party suit would better advance network goals. 
In equilibrium, agents commonly perform their contracts so there is a question how cases come to court. Section IV shows that contract members do not perform for or with potential beneficiary members - they "breach"for two reasons. First, as expected, contract members breach when performance costs rise or revenues fall. These breaches create vexing problems for courts and for parties. On the one hand, a breach motivated by increased costs (or reduced revenues) supports an inference that the contract member would otherwise have performed. The third party thus should win for the same reason an ordinary promisee wins; that a promisor's payoff turns negative cannot justify breach. On the other hand, the set of third parties that want to join a particular network may be larger than the set that the network can profitably support. Network members do not want to confer benefits on third parties when this would cost them money. The question cases sometimes pose, therefore, is whether a particular plaintiff is (or is not) in the set the network ex ante wanted to serve. It is difficult for courts to delimit the set of beneficiary members and it can be difficult for a network member to notify possible beneficiaries that their presence is wanted or not.

Second, and perhaps less obviously, network members breach by free loading. As an example, when the project is to discover information of commercial value the performance of contract members and third parties may be substitutes: agent A may benefit from the information that agent $\mathrm{B}$ develops. As a consequence, every agent has an incentive to invest less in developing information than it agreed to invest ex ante in the hope that other agents will invest more. Such defections reduce the likelihood of network success and, if parties anticipate them, may prevent a network from forming. Courts therefore should attempt to discourage free loading defections by ruling that injured third parties are beneficiary members. ${ }^{3}$

Our analysis in Section IV generates predictions of what courts that are partly responsive to economic considerations will do. Section $\mathrm{V}$ tests these predications against a random sample of recent third-party beneficiary cases. Here we attempt to enhance understanding of how courts handle network cases. We find the case outcomes largely consistent with three predictions: Third party claims are more likely to be granted (i) when the network member promisor becomes sufficiently aware of the third party, in the negotiation process or otherwise, to price the cost of serving that party: that network members can price the cost of serving particular possible beneficiaries suggests that the members ex ante

3 Damages may be an issue in these cases. Thus, if a network project never comes into existence, the payoffs it would have generated may be impossible to assess. In that case, courts could not award the standard expectancy remedy of putting the promisee in the same position performance would have done. Granting costs incurred may be the best a court can practically do. 
intended to serve those beneficiaries, (ii) when a potential beneficiary attaches substantial value to the performance, as is evidenced by the costs the beneficiary has incurred in preparation to perform (the existence and extent of these costs likely correlates positively with a reasonable beneficiary expectation that the network members intended to serve him), and (iii) when the network identifies its members in advance (the problem of delimiting the set of beneficiary members does not arise when network size is fixed ex ante).

Section VI next contrasts what courts actually do with what our normative analysis suggests that they should do. Here we show that current third-party doctrine is too restrictive when applied to network environments: Some third parties do prevail when this would advance contract member goals but other third party claims fail even though our normative criterion would argue that they deserve to be beneficiary members. As examples, a third-party plaintiff is less likely to succeed when the particular members of his possible beneficiary class become more difficult to identify. Yet, contract members may want to benefit members of such "vague classes" if they can anticipate class size. Moreover, courts do not require contract members to notify potential third parties that they intend to restrict service when notice is possible to give, and some courts create a strong presumption against finding third-party beneficiary liability. We argue that both of these rules are unjustified.

We summarize our findings in Section VII and emphasize several additional points in conclusion. First, one goal in this article is to facilitate the resolution of disputes where the contract is unclear about the right of third parties to recover for contract breach. Courts today will exclude third parties that dyadic contracts expressly exclude and they will include third parties that these contracts expressly include. But contracts are silent in many cases. Thus, a part of our purpose is to derive criteria for a "third party default." The current default is no liability unless the parties so intend. Under this default, intent can be manifested with the usual evidence: words, recitals, circumstances, actions. We accept this default but clarify it. When the usual evidence is inconclusive, courts commonly ask which interpretation would advance the parties' goals. The problem for current courts is that they do not understand what the parties' goals are in the network context, and how best to implement those goals. Our article fills in these blanks.

Second, we stress again that our analysis is preliminary. For many years, third-party beneficiary law has languished in the backwaters of contract: the subject is rarely taught, has been given only minimal scholarly treatment-the last serious article was published almost 23 years ago (Eisenberg 1992; Waters 1985) — and has been completely ignored by law and economics scholars. The law, however, is not waiting for scholarly wisdom. There has been a significant increase in the quantity of litigation in the past two decades. Our recent search 
found over 1,400 appellate cases between 2004-2014 involving claims to contract performance by third parties. These appellate cases are only the tip of the iceberg. In addition, while there has been much recent progress in network game theory, the economists, so far, have not studied the issues of breach and strategic defection that necessarily occupy lawyers. Hence, the existing economic wisdom is less helpful here than it usually is. Yet, despite the reasons for caution, we nevertheless believe that our positive and normative results will increase understanding of how the law affects, and can affect, network performance.

\section{THE INSTITUTIONAL SETTING}

The typical dyadic contract- "the bilateral contract" in legal languagespecifies a performance by a promisor to be rendered in exchange for a return promise or performance. Notions of freedom of contract as well as norms of efficiency and autonomy imply that the right to this performance only runs to the promisee or to his contractual designee. That only a party to a dyadic contract-a party in "privity of contract" - could claim the contract's benefits was the common law for several hundred years. Starting in the midnineteenth century, and moving at a faster pace today, courts have relaxed the privity rule to permit third parties to claim rights to a contract performance under certain conditions. In a recent case, Judge Richard Posner explained the new judicial intuition: If the parties to the contract make clear their intention that third parties are permitted to enforce the contract's terms, "permitting third-party-beneficiary suits is consistent with freedom of contract, and also reduces transaction costs by conferring rights (though of course not liabilities) on persons without requiring the persons to become involved in the contractual negotiations." 4 This central focus on the "intent" of the contracting parties as the precondition for extending rights to third parties remains the courts' core concern. Intent, however, is a conclusion, not a working concept. Other than express contractual language, courts have not clarified the factors that do and should generate the conclusion.

\subsection{The Evolving Common Law}

The rule precluding third party recovery against the contract parties prevailed in England until overturned by Act of Parliament in 1999. In the USA, thirdparty liability was first recognized in 1859 in Lawrence v. Fox. ${ }^{5}$ In that case, Fox

4 A.E.I. Music Network, Inc. v. Business Computers, Inc. et al., 290 F. 3d 952, 955 (7th Cir. 2002).

520 N.Y. 268 (1859). 
promised Holly that in return for a $\$ 300$ loan he would pay Holly's debt to Lawrence, who was not a party to the contract. The New York court held that the third party, Lawrence, could recover the amount of the loan directly from the promisor, Fox. Thus was born the so-called "creditor beneficiary" line of cases, granting a third-party beneficiary the right to a performance that would extinguish a debt owed that party by the promisee. ${ }^{6}$ Subsequently, in Seaver $v$. Ransom, ${ }^{7}$ the New York court extended enforcement rights to the third-party beneficiary when the promisee contracted with the promisor to secure a performance that was explicitly for the benefit of the third party. These were the "donee beneficiary" cases. ${ }^{8}$

The First Restatement of Contracts attempted to formalize these developments. ${ }^{9}$ It provided that a putative third-party beneficiary could recover directly from the promisor if the third party qualified as: (i) a donee beneficiary because the promisee intended to confer the promised performance as a gift to the third party, (ii) a donee beneficiary because the promisee intended to confer on the third party a right to the promised performance not based on any duty the promisee owed the third party, and (iii) a creditor beneficiary because the promisee intended to confer a right on the third party to recover from the promisor in payment of an obligation the promisee owed to the third party.

The First Restatement's formulation was short lived, however. Instead, courts began to substitute a broad standard of intent in place of the Restatement's more precise rules: The standard directed courts to ask whether the promisee (or in some courts both parties) intended to benefit the third party. Responding to the dominant trend in the case law, the Second Restatement of Contracts endorsed the intent standard and abandoned the labels "creditor" and "donee" beneficiary. Importantly, however, the Second Restatement added a further criterion for finding third-party beneficiary status. Section 302(1) provides that the third-party beneficiary is an intended beneficiary (and thus entitled to recover against the promisor) if (1) recognizing a right to the performance would effectuate the contract parties' intentions, and (2) ... the circumstances indicate that the promisee intended to give the beneficiary the benefit of the promised performance. Section (2) then provides that an incidental beneficiary is one who is not an intended beneficiary under section (1). ${ }^{10}$

6 See Restatement (Second) of Contracts $\$ 302$, comment b.

7224 N.Y. 233 (1918).

8 See Restatement (Second) of Contracts $\$ 302$, comment c.

9 Restatement (First) of Contracts $\$ 133$ (1932).

10 The concept of unqualified third parties as "incidental" beneficiaries was first developed by Judge Cardozo in H.R. Moch Co. v. Rensselaer Water Co., 247 N.Y. 160 (1928). 


\subsection{The Modern Rule}

Contemporary courts today retain the common law's no-liability default; that is, the courts generally follow the "intend to benefit" rule and limit third-party enforcement of contractual terms to intended, rather than incidental, beneficiaries. ${ }^{11}$ As Melvin Eisenberg (1992) has noted, however, "the term 'intent' is deeply ambiguous" along several dimensions: Does it mean acting with a motive to achieve a result or knowing the result is likely to follow? Does it refer to the "ends" the actor seeks to achieve or the "means" to those ends? (Kraus \& Scott 2009). Courts have yet to clarify the "intent" standard. ${ }^{12}$ A law and economics analysis would support an objective, functional test, but courts, lacking such an analysis, differ in their understanding of intent, looking variously to "clear", "express" or "definite" evidence of the promisor's contracting goals.

Despite the uncertainty that attends the intent test, the Second Restatement formulation, and in particular the distinction between incidental and intended beneficiaries, has been influential in framing judicial decisions in recent decades. In 1985, New York (the leading commercial jurisdiction in the USA) expressly adopted the Restatement test in Fourth Ocean Putnam Corp. v. Interstate Wrecking Co. ${ }^{13}$ Although judicial use of the intended/incidental distinction is common, the courts have not developed criteria for finding the parties' intent. Some courts follow a formalist "four corners" approach and require that intent be found in the express language of the written contract. ${ }^{14}$ But the majority of modern courts follows the Restatement's lead and looks to

11 See, e.g., Astra USA, Inc. v. Santa Clara County, Cal., 131 S. Ct. 1342, 1347 (2011) ("A nonparty becomes legally entitled to a benefit promised in a contract . . . only if the contracting parties so intend."). Accord, BIS Computer Solutions, Inc. v. City of Richmond, 122 Fed. App'x 608, 611 (4th Cir. 2005) (incidental beneficiaries may not bring breach of contract claims).

12 Eisenberg (1992) suggests that in place of the vague intent standard, courts substitute a "third party beneficiary principle": The third party can recover only if: (i) enforcement is necessary to effectuate both contracting parities' performance objectives (as determined by surrounding conditions, etc., etc.,) or (ii) enforcement is justified by reasons of policy or morality. Eisenberg (1992) then reviews a number of cases to suggest that his test explains the differing outcomes. The "third party beneficiary principle" seems unhelpful, however, because Eisenberg does not specify the reasons of policy or morality precisely. When all involved parties can contract with each other, they have the usual incentive to substitute precise rules for vague standards, such as the intent standard here. We are informed that construction trade associations in England advise their members to contract out of the Act of 1999.

1366 N.Y. 2d 38 (1985).

14 See e.g., Aetna Cas. \& Sur. Co. v. Fireguard Corp., 249 Va. 209 (1995). ("As Virginia is a state employing the "four corners' doctrine" one must show the "clear and definite intention" of the parties to confer a benefit upon the third party for third-party beneficiary status to emerge. The court is not free to look beyond the written contract when it is "complete on its face" with "plain and unambiguous" terms. Id. at 215.) See also, Nitro Distributing, Inc. v. Dunn, 194 S.W.3d 339, 345 
the surrounding circumstances to see whether the contract parties intended to confer rights on the putative third-party beneficiary. ${ }^{15}$ The Restatement approach thus is generally more hospitable to claims by potential beneficiary members, but it and the courts permit contract members expressly to exclude third-party liability. ${ }^{16}$

Consistent with a no-liability default, jurisdictions that allow extrinsic evidence to prove intent place the burden of establishing third-party beneficiary status on the party claiming it. ${ }^{17}$ Some courts go further to apply a "strong presumption" that a contract is intended for the benefit only of the contracting parties, but will accept an implied showing of intent to benefit third-parties when "the implication that the contract applies to third parties [is] so strong as to be practically an express declaration." 18 And in several jurisdictions, extrinsic evidence that an alleged third-party beneficiary was not an intended beneficiary of the contract may suffice to defeat claims even when the contract itself appears to create third-party rights. ${ }^{19}$

Important collateral issues arise as to when the promisor can raise a defense against the beneficiary's right to enforce the contract. The courts all agree that the alleged beneficiary has the burden of proving the "circumstances" that establish the necessary intent, and that the promisor can raise against the

(Mo. 2006) (" $[\mathrm{t}] \mathrm{o}$ be bound as a third-party beneficiary, the terms of the contract must clearly express intent to benefit that party or an identifiable class of which the party is a member").

15 See Sovereign Bank v. BJ's Wholesale Club, Inc., 533 F.3d 162, 168 (3d Cir. 2008) (applying Pennsylvania law and noting its adoption of the Restatement approach). Accord Klamath Water Users Protective Ass'n v. Patterson, 204 F.3d 1206, 1211 (9th Cir. 1999) (adopting Restatement approach to third-party beneficiary law).

16 See In re TJX Co. Retail Sec. Breach Litigation, 564 F.3d 489, 499 (1st Cir. 2009) (affirming dismissal of breach of contract claim by credit card issuer because contract between acquirer and merchant contained a clause stating "[t]his Agreement is for the benefit of, and may be enforced only by, Bank and Merchant ... and is not for the benefit of, and may not be enforced by any third party.").

17 See, e.g., ActiveVideo Networks, Inc. v. Verizon Communications, Inc., 694 F.3d 1312, 1335 (Fed. Cir. 2012) (applying New York law).

18 Quinn v. McGraw Hill Co., 168 F.3d 331, 334 (7th Cir. 1999) (investor is not a third-party beneficiary of contract between issuer and ratings agency and thus cannot recover for losses stemming from the credit downgrade of certain collateralized mortgage obligations). Accord Retro Television Network, Inc. v. Luken Commc'n, LLC, 696 F.3d 766, 769 (8th Cir. 2012) ("In Arkansas, '[a] contract is actionable by a third party when there is substantial evidence of a clear intention to benefit that third party."”).

19 See ActiveVideo, 168 F.3d at 1336 (Verizon alleged that it was the intended beneficiary of a contract between ActiveVideo and TV Guide that contained a covenant not to sue customers and licensees of TV guide. The court rejected this argument, even though Verizon was a customer and licensee of TV Guide, because ActiveVideo presented evidence that the covenant applied "only to licensees of the product that was to be jointly developed.") 
third party any defenses he has against the promisee (Scott \& Kraus 2013, p. 992). ${ }^{20}$ Courts also generally agree that the promisor and the promisee can mutually agree to modify the contract and that the beneficiary is bound by the modification. The beneficiary is typically entitled to recover verifiable reliance costs incurred prior to the modification but cannot recover her lost expectancy. ${ }^{21}$ A difficult question for many courts is whether the promisor can raise a defense that the promisee would have had against the beneficiary. Here the courts are split. Restatement section 309(3) does not permit the promisor to raise defenses other than those that render the contract voidable or unless the contract provides otherwise, on the doctrinal grounds that the beneficiary's rights are direct and not derivative. ${ }^{22}$

We conclude this summary of contract doctrine with two points that we will defend in the analysis that follows: (a) a strong presumption against permitting third parties to advance contract claims has no economic support, and (b) the modern receptivity to surrounding circumstances evidence gives courts a greater ability to ask the right questions, but it does not indicate what those questions are.

\subsection{The Increase in Third-Party Litigation and the Rise of Business Networks}

In the last several decades, there has been a marked increase in litigated claims of third-party beneficiary status. We discovered over 1,400 cases in the past decade (2004-2014) that discuss the distinction between intended and incidental beneficiaries. ${ }^{23}$ Many, if not most, of the cases involve disputes over the performance the promisor owes to the promisee and to potential beneficiary members and business networks feature in many of them.

In the current view, a contractual network consists of a number of independent firms that form relationships, some of which are contractual, in order to realize for network members co-ordination benefits that the firms would less efficiently achieve through vertical integration. Some networks have a "hub and spoke" design_-such as a franchise; others form a chain of bilateral contracts-i.e., "farm to fork" supply chains; others combine a hub with

20 Restatement (Second) of Contract $\$ 309(4)$.

21 See Restatement (Second) of Contracts $\$ 311$. We argue below that restricting a beneficiary to a reliance recovery is inefficient in some cases.

22 According to the Restatement, the third party is not subject to defenses that the promisor had against the promisee, except for fraud or other infirmity that makes the contract voidable $a b$ initio or other defenses based on impracticability or public policy. Restatement (Second) of Contracts $\$ 309(1)(2),(3)$.

23 See Dane Thorley, Analysis of Third Party Claims in Random Sample of Contracts, 7/17/2014 (memo on file with the authors). 
lengthy spokes consisting of chains of contracts, such as a large construction project. And still others form a cluster of firms whose membership shifts over time. Here the primary exemplars are standard setting alliances, credit card networks and the tech transfer network consisting of a university/research entity, a number of biotechs, large pharmas and venture capital firms (Powell, Koput \& Smith-Doerr 1996; Powell 1996)). The network form implicates the issue of third-party rights when network members contract only with their neighbors but these contracts affect other members or potential members.

Networks commonly enforce agreements among members relationally, relying on the standard mix of reputation, repeat play and tit for tat reciprocity. But standard theory would predict that informal enforcement fails in many settings. The key question then becomes when would inter-party legal liability advance network goals? ${ }^{24}$ The courts' inability to come up with predictable answers to this question accounts for much of the current litigation.

We begin to fill this gap by confronting a first order question: Why can't agents write a "master contract" that explicitly binds network members? The answer is that sometimes they do. General Motor's master contract for its dealers binds them all as does John Deere's relationship with its suppliers. ${ }^{25}$ Master contracts typically only work in hub and spoke arrangements or in stable supply chains, however. Otherwise, master agreements cannot solve the relevant contracting problems. In many cases, the size of the network generates collective action and coordination problems. Moreover, the networks are often not stable- the membership changes over time. Technology and the information revolution have increased the levels of uncertainty and, in turn, this has led to an ongoing search for new partners. In consequence, in many business networks the master contract solution is impracticable owing to excessively hightransactions costs.

24 The German scholar Gunther Teubner (2011) has written extensively about networks and has considered the question of contract members liability under the Civil Code. He argues that the essential elements for granting legal rights to third parties are: (i) a constellation of connected contracts, (ii) mutual referencing of these contracts to one another (i.e., contracts refer to activities governed by other contracts), (iii) a network purpose (separate from the purpose of the individual bilateral contracts), and (iv) intensive factual cooperation between all the different parties, not merely those bound by explicit bilateral contracts (i.e., a relational enforcement mechanism). Italy has recently adopted legislation designed to facilitate the enforcement of network contracts (Ferrari 2010) (noting Italy's 2009 adoption of a "Network Contract Law”).

25 See e.g., Component Supply Agreement between American Axle \& Manufacturing, Inc. and General Motors Corporation (June 5, 1998) (requirements contract for motor vehicle components to be supplied by AAM to GMM); Long Term Agreement between John Deere \& Company and Stanadyne Corporation ( 5 year supply contract for the purchase of fuel filtration systems, injection nozzles and related products by Deere from Stanadyne). 


\section{THE NETWORK CONTEXT}

We introduce here frequent network types that feature in the cases. Credit card networks occupy considerable judicial time. These networks are composed of "issuers," financial institutions that issue credit cards to consumers pursuant to bilateral contracts, and "acquirers," banks that process payments for merchants who agree to accept credit cards as payment for their goods and services. ${ }^{26}$ Each bank in the network has a membership agreement with the network operator (e.g., Visa) that allows the bank either to issue credit cards to its customers or to process payments from merchants. Because merchants do not contract directly with issuers, disputes between these parties may raise third-party beneficiary claims. Sovereign Bank v. BJs Wholesale, presents a representative fact pattern. ${ }^{27}$ In this case, credit card information pertaining to cards issued by Sovereign Bank was stolen from BJ's Wholesale Club. Sovereign Bank sued BJ's for breach of contract, alleging that it was the intended third-party beneficiary of an agreement between BJ's and an acquirer that prohibited BJ's from retaining credit card information beyond a certain period of time. ${ }^{28}$ The Third Circuit held that a genuine issue of material fact existed regarding Sovereign Bank's status as a third-party beneficiary based upon the deposition of a Visa representative $e^{29}$ and a memorandum detailing the purpose of the restrictions on retaining cardholder information. ${ }^{30}$ Sovereign Bank is notable because it provides a recent example of a court relying on thirdparty beneficiary law to enforce a credit card network contract in the absence of an express contractual provision designating third parties as beneficiaries.

Standard-Setting Organizations (SSOs) form networks with members who rely on industry standards to "establish technical specifications to ensure that products from different manufacturers are compatible with each other."31

26 See, e.g., Sovereign Bank, 533 F.3d at 164 (describing credit card networks). Cf. A.E.I. Music Network, Inc. v. Bus. Computers, Inc., 290 F.3d 952, 955 (7th Cir. 2002) (noting that when a clear intent to benefit third-parties exists "permitting third-party-beneficiary suits is consistent with freedom of contract, and also reduces transaction costs by conferring rights ... on persons without requiring the persons to become involved in the contractual negotiations").

27533 F.3d 162 (3rd Cir. 2008). But see In re TJX Co., supra (concerning a similar fact pattern, but reaching a different result on the merits); In re Heartland Payment Systems, Inc. Customer Data Sec. Breach Litig., 834 F. Supp. 2d 566 (S.D. Tex. 2011) (same).

28 See id. at 168 .

29 The representative testified that "[ $[\mathrm{t}]$ he purpose of the [restriction on retaining cardholder information] ... is to maximize the value to the Visa system as a whole." Id. at 169.

30 See $i d$. at 170 (describing the purpose of the restrictions as " $[\mathrm{t}]$ o protect the Visa system and Issuers from potential fraud.”).

31 Microsoft Corp. v. Motorola, Inc., 696 F.3d 872, 875 (9th Cir. 2012). 
Because standards may require the use of patented technology, SSOs often attempt to prevent patent holdups by requiring members who hold IP-rights in standard-essential patents to license their patents to other members on reasonable and non-discriminatory (RAND) terms. ${ }^{32}$ These networks appear at least somewhat effective in ensuring the licensing of standard-essential technology. Generally, only patent holders and the SSO itself are parties to the contracts; this requires other members of the network to bring suit as third-party beneficiaries when they believe that a patent holder has breached its contract to license on RAND terms. ${ }^{33}$ Many members of SSO networks believe that the promise to license patents on RAND terms can (and should) be enforceable by other members of the network. In Microsoft Corp. v. Motorola, Inc., for example, the parties did not dispute that Microsoft was a third-party beneficiary of the contract between Motorola and the SSO and instead focused their litigation on the issue of whether Motorola's proffered terms were reasonable. ${ }^{34}$

Networks also exist between hospitals, hospital service providers, patients, insurers, and HMOs. Here, for example, we find doctors suing hospitals or insurance providers for the services that are authorized. ${ }^{35}$ Some cases involve policyholders suing reinsurers as third-party beneficiaries of agreements with direct insurers. ${ }^{36}$ Perhaps the most frequent category are cases in which patients sue as third party beneficiaries of contracts between hospitals and service providers. ${ }^{37}$ There are also cases involving relatives of patients, notably parents, suing hospitals in their own capacity as purported third-party beneficiaries. ${ }^{38}$ These "hospital network" cases couch their discussion in terms of the "intentions" of the parties or the contracts involved: they have proved remarkably hostile to third-party beneficiary claims. ${ }^{39}$ For example, in a paradigmatic case

32 See id. at 876

33 See, e.g., Apple Inc. v. Samsung Electronics Co., No 11-CV-01846, 2012 U.S. WL 1672493 (N.D. Cal., May 14, 2012) (Apple alleged that it was a third-party beneficiary of contract between Samsung and SSO).

34696 F.3d 872, 878 (9th Cir. 2012). But see Apple Inc. v. Samsung Electronics Co., 2012 WL 1672493, at ${ }^{*} 12$ (Samsung moved to dismiss Apple's breach of contract claim on the grounds that the RAND agreement was an unenforceable "agreement to agree").

35 See e.g., Joseph v. Hosp. Serv. Dist. No. 2 of Parish of St. Mary, 939 So. 2d 1206 (La. 2006).

36 See e.g., Koken v. Legion Ins. Co., 831 A.2d 1196 (Pa. Commw. Ct. 2003); Considine v. Reliance Ins. Co., 35 A.3d 1232 (Pa. Commw. Ct. 2011).

37 See e.g., Jenkins v. Best, 250 S.W.3d 680 (Ky. Ct. App. 2007); Dorr v. Sacred Heart Hosp., 228 Wis. 2d 425 (Wis. Ct. App. 1999).

38 See e.g., Ward v. Glover, 206 S.W.3d 17 (Tenn. Ct. App. 2006).

39 Koken, 831 A.2d at 1237; Dorr, 228 Wis. 2d at 450 (notably finding such a right for HMO subscribers despite an explicit provision of the contract barring third party beneficiary claims except those "specifically provided herein"). 
of a patient's claim of third-party rights in a contract between a hospital and a medical service provider for the institution, the court held that the patient's medical services were incidental (neither the "direct [or] primar[y]" reason for the contract) and accordingly she did not have a claim as a third-party beneficiary. ${ }^{40}$

Third party claims also arise frequently in franchise networks. Here the disputes vary, sometimes involving claims by franchisees (either existing or potential) arising out of contractual obligations assumed by the franchisor in the master franchisee contract. A few examples illustrate the typical patterns. In Chu v. Dunkin' Donuts Inc., ${ }^{41}$ the claimant was a rejected prospective franchisee, suing on a settlement agreement between the franchisor (Dunkin') and former franchisees. The relevant provision at issue stated that Dunkin' would "not unreasonably withhold approval to a prospective transferee." The court found that the purpose of the agreement was to settle litigation between Dunkin' and the former franchisees. Thus, rather than being included for the benefit of any transferees, the clause was included only for the benefit of former franchisees who were parties to the settlement contract. On the other hand, in Hawkinson v. Bennett, ${ }^{42}$ a sales franchisee brought a claim for a breach of the agreement between the franchisor and master franchisee. The contract made explicit mention of the duties of the master franchisee to other franchisees established in his area, providing that the "demonstration systems" mentioned in the contract were explicitly "for the use of the Sales Franchisees." The court thus held that sales franchisees were third-party beneficiaries as a matter of law.

And finally, third party claims are frequently filed in disputes over defective or failed performance in large construction projects where the litigation centers on disputes between the owner of the project and various sub-contractors whose primary contractual relationship is with the general contractor. Here the courts are split. Some courts have held that the third party claim is too far removed, creating only an incidental benefit to the plaintiff, ${ }^{43}$ while others have permitted the third party claim to go forward. ${ }^{44}$

40 Jenkins, 250 S.W.3d at 696.

4127 F. Supp. 2d 171, 174 (E.D.N.Y. 1998).

42265 Kan. 564, 594 (1998).

43 See e.g., Kisiel v. Holz, 272 Mich. App. 168 (2006); Fifth Third Bank v. Cope, 162 Ohio App. 3d 838 (2005); Pierce Associates, Inc. v. Nemours Found., 865 F. 2d 530 (3d Cir. 1988); Safer v. Perper, 569 F2d 87 (D.C. Cir. 1977). But see Levan v. Richter, 152 Ill. App. 1082 (1987) and McCall v. Towne Square, Inc., 503 S.W. 2d 180 (Tenn. 1973).

44 Aetna Cas. \& Sur. Co. v. Fireguard Corp., 249 Va. 209 (1995); A.E.I Music Network, Inc., v. Business Computers, Inc., 290 F. 3d 952 (2002); Guardsman Elevator Co., Inc., v. United States, 50 Fed.Cl. 577 (2001). 
We next ask more generally why parties form networks and what can go wrong. The article then tests the predictions that follow from our analysis against a random sample of recent third-party beneficiary cases. Here we consider whether the patterns of liability that we find in the cases are consistent with the economic considerations we analyze. We also explore the factors that allow third parties in some networks, but not others, to overcome the presumption against third-party liability.

\section{NETWORK ANALYSIS 45}

It is helpful to begin an analysis of the economic underpinnings of networks with some basic terminology. Each agent in a network is identified with a "node." The links between agents reflect their interactions; connected agents are "neighbors." Network agents may or may not contract with each other, but we analyze here the cases where they do. In network parlance, an agent's "degree" is the number of connections she expects to have. We assume that agents can predict their degrees accurately but not the degrees of other agents. Thus, an agent can only contract with one or more of her neighbors.

\subsection{Strategic Complements}

In network theory, agents' actions can be either strategic complements or strategic substitutes. Actions are strategic complements when the marginal benefit that agent $\mathrm{i}$ realizes from an action is greater when more of her neighbors do the same. For an example: "A network is a group of consumers who consume the same good or a compatible good. The network confers network benefits if the utility it provides to each individual user increases with the total number of users. An example of a good with network benefits is text-editing software" (Scotchmer 2004). In cases such as this, agents agree to make complementary investments to develop a product: software, a new drug, a chemical reagent. The complementary action category is general, however. Referring to the hospital example above, the larger the patient population becomes, over a range, the

45 There is a well-known problem when analyzing networks: "A critical problem for network theory is that even simple games have multiple equilibria, so that a great variety of outcomes are consistent with theoretical analysis. This naturally limits the predictive power of the theory and the scope of policy recommendations, since multiple equilibria make it difficult-to-impossible to offer definitive advice regarding how such labor markets, search markets, etc., should be organized (Charness et al. 2014)." We largely abstract from this concern because our limited goal is to see how third party beneficiary liability would advance the goals of network members. Nevertheless, the limited utility of the theory for policy analysis should reinforce the tentative nature of the recommendations we make. In the Charness et al. experiments, the players often chose one of the possible equilibria. We note when these choices are relevant to our claims. 
more the hospital can avail itself of economies of scale and predict its demand. Reducing the costs and increasing the performance of the hospital, in turn, makes the hospital a better resource for service provider members. Further, the more hospitals that agree to join the network, the greater the payoff to the service provider itself.

Formally, a promisee, $\mathrm{P}$, agrees to pay a promisor, A, to perform an action $\mathrm{x} \varepsilon$ $\mathrm{X}$ that may benefit a nonparty $\mathrm{B}$. $\mathrm{P}$ and $\mathrm{A}$ thus are contract members and $\mathrm{B}$ is a possible beneficiary member. As above, $\mathrm{x}$ may be interpreted as making an investment in developing something new or increasing service capacity. The action is expected to cost $\mathrm{c}(\mathrm{x})$. If $\mathrm{A}$ performs, $\mathrm{P}$ gets the payoff $y_{p} \equiv x_{A}+\sum_{j N_{i}} x_{j}-z$, where $\mathrm{x}_{\mathrm{A}}$ is the action of contract member $\mathrm{A}, \mathrm{N}_{\mathrm{i}}$ is the set of P's neighbors so the second term is the aggregate action in $\mathrm{N}_{\mathrm{i}}$, and the last term is the price $\mathrm{P}$ pays to $\mathrm{A}$ to perform the action. The notation indicates that $\mathrm{a}$ promisee contract member benefits from the action of her contract partner and also may benefit from the actions of other agents, who are in or later join the network. The promisor A's expected payoff is $\mathrm{y}_{\mathrm{A}}=\mathrm{z}+\Sigma \mathrm{j}_{\mathrm{Ni}} \mathrm{x}_{\mathrm{j}}-\mathrm{c}(\mathrm{x})$; B's expected payoff is $y_{B} \equiv x_{A *}+\sum_{j N_{i}} x *_{j}$, where the star indicates that B's benefit may differ from P's benefit. For example, $\mathrm{P}$ may be a service provider who benefits from receiving insurance premiums while $B$ is an insured who benefits from receiving covered treatment at a hospital. We assume that contract member revenues are increasing in the number of members and that the promisor has convex costs. ${ }^{46}$ These assumptions imply that the network has an optimal size. ${ }^{47}$

A recent example of a real world strategic complements network case is Peters v. Monroe Township Board of Trustees. ${ }^{48}$ Human capital investments are strategic complements when agent i's investment is marginally more beneficial when others also invest. In the case, firefighters had to take a physical exam. The investment was in the human (physical) capital needed to pass: other firefighters, and their fire department, benefit when each firefighter becomes more fit. The Trustees of the fire department contracted with WorkHealth to

46 Technically, we assume that $c(x)=\frac{1}{2}\left(x c^{2}\right)$. A network may have many promisees, promisors (who are supposed to take actions) and potential beneficiaries. The notation is in the singular for convenience.

47 Network size may be optimal for the members but inefficient. For example, a network can be too big or too small from a social point of view. For a general analysis, see Galeotti et al. (2010). We do not consider the complex case in which network members cooperate in producing knowledge but compete with each other in the product market. Consistent with the model here, however, in this case network size is a negative function of the cost of forming links (i.e., serving agents), and these networks also exhibit threshold effects. These effects are considered infra. Dawid \& Hellmann (2014) and Hattori \& Hsin (2014) analyze cooperate/compete networks. 
perform the examinations. The Trustees probably assumed that firefighters who expect competent examinations would be motivated to invest in health in order to pass. In our terms, the contract members thus were the fire department and Workhealth and the potential beneficiary members were the firefighters. The plaintiff/beneficiaries claimed that WorkHealth arbitrarily lowered their health test scores, leading to their suspension and loss of employment. The court concluded that plaintiffs satisfied the pleading requirements for a third-party beneficiary claim because the contract was meant primarily to benefit the employees.

\subsection{Strategic Substitutes}

Actions are strategic substitutes when the marginal benefit that an individual obtains from an action is lower when more of her neighbors also choose that action. An example is commercially exploitable information. To illustrate, assume a set of companies produce similar food products. Any of these products may become contaminated by a genetically modified strain. Each company can perform tests to determine if its product is contaminated. Because the products are similar, one company's test results would benefit the others by increasing their knowledge of contamination, and so providing a better opportunity to reduce it. The companies agree with each other to perform tests and to disclose the results. In this example, one agent's contribution may reduce the need for other agents to contribute. For example, food company $\mathrm{P}_{\mathrm{i}}$ may reduce its research budget in the hope that company $\mathrm{P}_{j}$ will research more extensively.

A slightly different model is helpful for analyzing strategic substitute networks. ${ }^{49}$ There are A agents, each of whom simultaneously chooses an action $\mathrm{x} \geq 0$. The notation $\mathrm{x}_{-\mathrm{i}}$ denotes the actions of agents other than i. Let $\tau \varepsilon[0,1]$ represent the substitutability of agent $j$ 's actions for agent i's actions, where $\tau=1$ is perfect substitutability. Agent i's marginal cost is $\kappa_{i}>0$, so his payoff from choosing action $\mathrm{x}_{\mathrm{i}}$ is

$$
\mathrm{U}(\bullet)=\pi_{\mathrm{i}}\left(\mathrm{x}_{\mathrm{i}}+\tau \Sigma \mathrm{jx}_{\mathrm{j}}\right)-\kappa_{\mathrm{i}} \mathrm{x}_{\mathrm{i}}
$$

An agent receives the payoff from his action, the first term in the parenthesis, and the payoff from the actions of linked agents that benefit him, the second term in the parenthesis. The agent, however, must pay his cost, the last term in the Expression.

We denote agent i's best reply to the actions of the other agents $f_{i}\left(x_{-i}, \tau, G\right)$, where $G$ denotes the character of the network. To find $f_{i}$, first let $\pi^{\prime}(\bar{x})=\kappa_{i}$ : that is, action $\bar{x}$ equates agent i's marginal costs to her marginal benefits. 
Then maximizing the Expression with respect to $\mathrm{x}_{\mathrm{i}}$ yields ${ }^{50}$

$$
\begin{aligned}
& \text { (a) } \mathrm{f}_{\mathrm{i}}=\bar{x}-\tau \Sigma_{\mathrm{j}} \mathrm{x}_{\mathrm{j}} \text { if } \tau \Sigma_{\mathrm{j}} \mathrm{x}_{\mathrm{j}}<\bar{x} \\
& \text { (b) } \mathrm{f}_{\mathrm{i}}=0 \text { if } \tau \Sigma_{\mathrm{j}} \mathrm{x}_{\mathrm{j}} \geq \bar{x}
\end{aligned}
$$

To understand these first order conditions, recall that $\tau$ represents the degree of substitutability between agent j's actions and agent i's actions when the two agents are linked. Then condition (a) says that agent i's payoff is increasing in the action he takes when the degree of substitutability is relatively small. Condition (b) says that agent i will become inactive when the degree of substitutability becomes relatively large; his best response then is to let agent $j$ act. Notice also that as $\tau$ increases (from zero toward one) agent i's activity level falls.

An analysis of defection should also consider the effect of an agent's degree. ${ }^{51}$ An agent's incentive to be active likely is decreasing in her degree. Intuitively, if an agent has many neighbors, the agent may reason that at least one of them will invest and this will reduce her incentive to be active. Conversely, if the agent has few neighbors, she may reason that if she does not invest no one else will. Thus, holding technical substitutability constant, the agent's incentive to defect is increasing in her degree. ${ }^{52}$

\subsection{Reasons for Breach}

\subsubsection{Strategic Complements}

In the strategic complements case, agents breach for traditional reasons: they realize increased costs or reduced revenues. A hospital, for example, restricts the number of service provider members it will admit as care costs increase relative to the fees the service provider has agreed to pay. Breach in the strategic complements case poses significant difficulties for courts applying third-party beneficiary doctrine and for network members.

50 Here, $\mathrm{U}(\bullet)$ is differentiable, strictly increasing and concave in $\mathrm{x}_{\mathrm{i}}$ and the conditions for an internal solution to agent i's maximization problem are commonly assumed.

51 Recall that an agent's degree is the number of connections with other agents in the neighborhood of the agent's link she expects to make.

52 Francesco \& Pin (2014) develop a formal analysis of incentives in these games, that derives the result summarized above. The Charness et al. (2014) experiments find: "The observed effects of degree and connectivity on activity support the notion of threshold equilibria, which implies a negative relationship between degree and activity with substitutes, but a positive one with complements." See also, id. at 1640-1641. The threshold equilibria in strategic substitute networks are higher than the text above suggests when a member's investment increases the member's ability - its "absorptive capacity" - to learn from the investments of other members. Nevertheless, above a certain substitutability level a member will curtail its investment in order to freeload on the investments of others. See Correani et al. (2014). 
To see why, recall that a strategic complements network has an optimal size: that is, the contract members' expected profits are maximized at a particular membership. If actual costs or revenues turn out to be low, the network ex post may want to serve fewer members than it anticipated it could serve profitably. Using a little notation, consider the case in which expected network profits were maximized at service quantity $\mathrm{q}^{\star}$ but actual profits turn out to be maximized at service quantity $\mathrm{q}^{\mathrm{a}}<\mathrm{q}^{\star}$ because the costs of serving third parties rose. Potential third-party beneficiary members, however, may have (reasonably) expected the higher service level. Because only ex ante expectations count, these agents should recover the benefits they anticipated. Using the notation here, the network promisor should be liable for failing to serve agents in the $\mathrm{q}^{*}-\mathrm{q}^{\mathrm{a}}$ interval.

The courts' difficulty arises because too many potential agents may want to join-to consume network services. ${ }^{53}$ Continuing with our notation, let the maximum demand for a network be $\mathrm{q}^{\mathrm{m}}>\mathrm{q}^{*}$. Contract members do not want to benefit demanders in the $\mathrm{q}^{\mathrm{m}}-\mathrm{q}^{*}$ interval because they could not serve these demanders profitably. The problem for a court, when a potential beneficiary member sues a contract member, is to decide whether the plaintiff is in the ex ante efficient interval $\mathrm{q}^{*}-\mathrm{q}^{\mathrm{a}}$, where he should recover, or in the ex ante inefficient interval $\mathrm{q}^{\mathrm{m}}-\mathrm{q}^{*}$, where he should not. Figure 1 may clarify this analysis.

\section{Figure 1.}

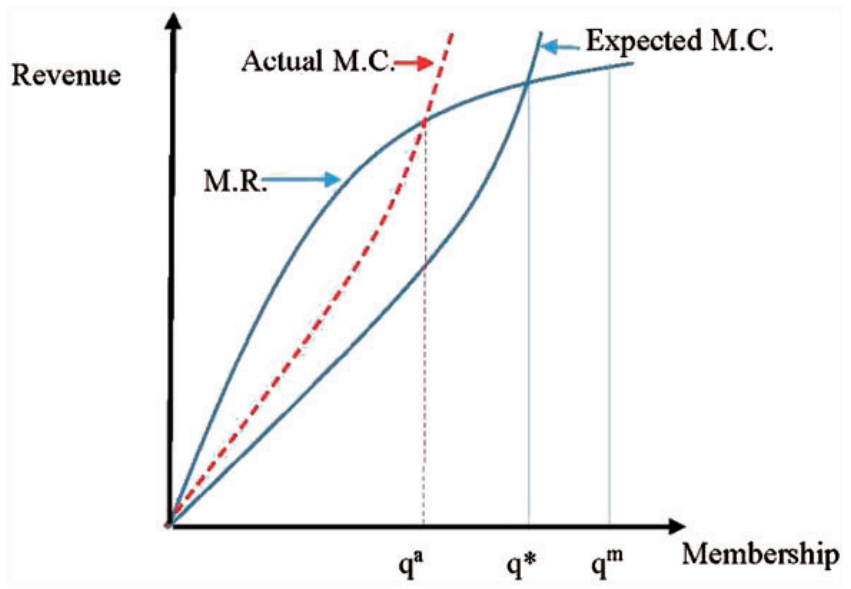

53 The theory suggests that this is a real danger: because network member payoffs are increasing in the number of players, some possible equilibria of strategic complement networks can have too much participation. In the Charness et al. experiments, supra note 53, agents tended to play the excess activity equilibria: "The effects of degree are consistent with our hypothesis, as there is more activity with higher degree with both complete and incomplete information.” Id. at 1656. 
The solid convex curve represents expected marginal costs; the dashed convex curve represents realized marginal cost. Contract members expected to serve up to $\mathrm{q}^{\star}$ demand profitably, but can actually serve the smaller $\mathrm{q}^{\mathrm{a}}$ demand profitably. The members never intended to serve demand in the $\mathrm{q}^{\mathrm{m}}-\mathrm{q}^{*}$ interval because marginal cost would exceed marginal revenue there.

It is difficult for a court to demarcate efficient from inefficient demand, as seen by contract members, because marginal costs (and revenues) are difficult for courts to recover. The courts' problem is also the contract members' problem: ex ante, the members want to encourage demand up to level $\mathrm{q}^{\star}$ and to discourage demand above, but there is a question whether they can effectively notify potential joiners that service is restricted to the $\mathrm{q}^{\star}$ level.

We return to these issues in Section VI when considering remedies, but as prelude to our empirical study of the cases, our analysis here predicts that courts will respond to the excessive demand issue by permitting third party claims to proceed in some circumstances but not others. More precisely, we predict that courts would permit third parties to recover (a) when the contract between network members and the circumstances indicate an intention to benefit the third party claimants, (b) when the beneficiary class size is fixed ex ante, and (c) when the plaintiff has incurred substantial costs. In case (a), the best inference from a contract evidencing an intent to benefit is that network members do not anticipate excessive demand-demand above $\mathrm{q}^{\star}$. The most important accompanying circumstance is the contract members' ability to price the cost of serving putative beneficiaries. Because excess demand is unprofitable, a network's ability to anticipate losses from serving particular beneficiary types suggests that the network meant to exclude those types. In case (b), there cannot be a danger of excess demand when class size is fixed in advance. ${ }^{54}$ And in case (c), reliance is a good proxy for distinguishing efficient from inefficient demand if a third party expectation that he will be served correlates positively with the ex ante profitability for network members of serving him. That the correlation is positive seems a plausible assumption for a court to make. ${ }^{55}$

54 The Monroe Township case, supra, may illustrate the latter criterion. The number of affected firefighters was fixed in advance: the fire department employees. Similarly, courts are sympathetic to third-party beneficiary claims in franchise contexts. See, Hawkinson v. Bennett, supra note 50. The class of franchisees often is fixed in advance by contract. In contrast, courts are reluctant to accord third-party beneficiary status to insureds who want to consume hospital services. See authorities cited supra notes 43-47. The danger of excess demand seems real in the insurance company/hospital context.

55 In Section VI below, we show that liability can be ex post inefficient in this case even when a plaintiff is in the efficient $\mathrm{q}^{*}-\mathrm{q}^{\mathrm{a}}$ interval. This is because, as in the model above, the contract parties sometimes do not require the third party to pay a price. As a consequence, a third party may sue 


\subsubsection{Strategic Substitutes}

In both strategic complement and strategic substitute networks the possibility of freeriding creates an incentive for breach. There is a strategic substitute aspect to complementary investments when the investments are informative to others regarding costs or demand (Schwartz \& Scott 2007). In this circumstance, the information that a particular agent's investment reveals reduces the incentive of the other agents to invest. In the limit, an agent may delay its investment altogether until she observes the behavior of the other agents. If the project is revealed to be promising, this agent invests; if not, she defects. Because every agent has the same incentive, the equilibrium may involve no activity: so many agents anticipate defection that the network does not form. Cases come to court, however, when network activity begins but defections along the way derail the network's project.

Much the same analysis applies to agents that are linked in a strategic substitutes network. The agents may agree with each other to encourage everyone to invest efficiently. The strength of the incentive to defect from such contracts is increasing in the substitutability between an agent's actions and the actions of other agents and in an agent's degree. When substitutability is strong and degree is high, the possibility of defection may prevent a network from forming initially. As the effect of these factors diminishes, the likelihood of formation increases, and then the legally relevant case has the agents starting but not finishing.

This analysis suggests that when a network is characterized by strategic substitution, a plaintiff-a possible beneficiary member-will have invested in a network project that did not ultimately form. He then sues other agents that have behaved strategically by investing too little or by not investing at all. When there is no network project, however, the plaintiff cannot sue for her expectation: the payoff she would have realized from a successful venture. Some plaintiffs may have incurred verifiable reliance costs, however. Hence, our analysis predicts that there will be cases in which plaintiffs associated with networks sue for these costs, and our analysis uncovers such cases. In contrast, in the strategic complements case, plaintiffs also likely incur reliance costs, but may also have a provable expectation. There is no reason, we argue in Section VI, not to protect it.

To summarize, the analysis here suggests four factors that courts may, and should, consider when deciding whether a third party is a beneficiary member: (i) the terms of the contract between the contract members of the network, and the accompanying circumstances, (ii) material investments by the third party plaintiff that support an inference that network parties expected each other to 
be beneficiary members as well as contract members, (iii) the degree of substitutability between the network members investments because the incentive to defect is strong when it is high, and (iv) the defendant's degree (or number of connections) because the incentive to defect also is increasing in her degree.

\section{TESTING THE ANALYSIS: THE CASE SAMPLE}

The network analysis in Section IV provides the basis for both a positive and a normative analysis of third-party beneficiary cases. We first address the positive question by identifying the economic factors that apparently explain the case outcomes. Teasing out these factors is particularly important, but also difficult, because courts frame their decisions in terms of the conclusory, and elusive, intent standard.

\subsection{Initial Hypotheses}

We created a random sample to explore the positive and normative factors that Section IV develops. The case analysis tests three hypotheses: First, courts are more likely to accord beneficiary member status to a third party when the contract members appear sufficiently well informed about the beneficiary class to which the member belongs to price a contract member's performance. This hypothesis rests on the strategic complements property that adding beneficiary members increases the payoff of contract members, but only over the ex ante efficient range. That contract members can price serving a particular beneficiary class suggests that it is efficient to serve class members such as the plaintiff. ${ }^{56}$ Second, courts are more likely to accord beneficiary member status to a third party when that party values the promisor member's performance highly. These are the strategic complement and strategic substitute cases in which plaintiffs incur reliance costs. Third, claims by third-party members of a business network against other members are more likely to succeed than claims brought by third parties who are not in a network. Two reasons imply this hypothesis. First, when network size is fixed ex ante, the problem of excessive

56 A second possible basis for this hypothesis is that a promisee will litigate a defective tender of performance only when the expected damages award exceeds the costs of enforcement. Because attorneys' fees and opportunity costs cannot be recouped in litigation, there is, in general, an under-enforcement of defective performances. As a consequence, the contract member promisor will reduce his efforts to ensure that the performance meets the contract specifications by the amount of the reduction in his expected liability from tendering a defective performance. If third parties have lower enforcement costs than the promisee, granting rights of enforcement to these additional potential plaintiffs will increase the promisor's effective damage liability for breach. In this way, the extension of third-party rights serves as a warranty that the promisor will expend additional efforts to ensure that his performance actually meets the quality standards required in the contract. And in that sense, a default rule extending a right to enforce the contract to particular third parties is analogous to an implied warranty of fitness for a particular purpose. 
demand does not arise: network agents have already decided whom it is profitable to serve. The best inference this decision supports is that it would be unprofitable to serve nonmembers. We thus predict that courts are inclined to deny nonmember claims. Second, stepping outside the formal analysis above, the forces that govern cooperation among the members of some business networks are durable, with trust and cooperation increasing with participation in the network (Powell 1990). When there is recognition of common interests and a high probability of future association, parties are more likely to cooperate for mutual gain and are also more willing to enlist the aid of courts in punishing defectors (Axelrod 1984; Powell 1996). We expect courts to be complicit in this enterprise

\subsection{What do Courts Actually Do?}

\subsubsection{The Random Sample}

In order to create a database to evaluate the enforcement decisions of contemporary American courts in third-party beneficiary cases, we generated two samples from litigated cases between 1994 and 2014. An initial non-random search for contracts cases that included references to intended and incidental beneficiaries yielded 3,045 cases. ${ }^{57}$ Understanding that conclusions drawn from the nonrandom sample were possibly a reflection of selection bias, we subsequently performed a further, randomized search for cases that featured third party claims. This sample, while moderate in size, provided a dataset that should be, in expectation, an accurate reflection of US courts' current practices regarding third-party relationships. ${ }^{58}$

To identify the population of applicable cases, we used the terms "third party beneficiary" and "intended beneficiary" in Google Scholar's new case law engine. ${ }^{59}$ Results were limited to US state and federal cases decided between

57 Many of the cases are litigated at the summary judgment stage. In most of those cases where the court denies summary judgment, it held that the third-party beneficiary has the right to attempt at trial to establish the facts on which her claim depends. Apparently, none of those cases resulted in later reported litigation.

58 There is no way to ensure the external validity of our sample (the cases available for search using Google may, for example, be of a certain type), but because we selected the cases from the population in a uniformly random manner (each case was randomly selected with an equal probability of $1 / 1,406)$, the distribution of any given attribute or variable in the sample should match the distribution of that attribute in the population.

59 Google Scholar's case search engine is a new and relatively untested method for formal legal research, but we decided to use it over more traditional search engines such as Lexis and Westlaw for a variety of reasons. First, a series of comparative trials between Google, Lexis, and Westlaw using a number of potential search terms (discussed below) resulted in similar outcomes in terms of the number of cases found. Second, Google proved to be easier to work with on a day-to-day basis. Third, and 
2004 and $2014 .^{60}$ This process resulted in a sample of 1,406 cases. Using Microsoft Excel, each case was assigned a random number from 0.000 to 1.000. Cases were then organized in ascending order according to these random numbers. ${ }^{61}$ The first sixty of these cases were read and coded in the random order created by the computer. Twenty-five cases that contained our search terms but were either completely unrelated to third-party contract claims or were of a case type that were not of interest (most commonly dutyestablishing tort cases, attorney malpractice suits, or testate conflicts) were excluded from the sample in addition to one case that had been drawn twice, resulting in thirty-four cases of interest. We coded each of these cases for whether the court found in favor of the third-party claimant (whether as a final judgment, summary judgment, or a judgment on the pleadings); and then coded the cases to test our three initial hypotheses: (i) whether the third-party claimant was a member of a class or group either explicitly referred to or otherwise identified in the disputed contract, so that serving the class could be priced, (ii) whether the parties were members of a business network, and (iii) whether the claimed losses were substantial. ${ }^{62}$

possibly most importantly, the free and simple nature of the search engine lends itself to easier replication by outside researchers.

60 We explored a number of search terms in the preliminary stages of the research. Using "network contract", "contractual network", "third party creditor beneficiary", or "business network" in combination with our base term, "third party beneficiary" did not yield enough cases to draw a sufficiently large random sample. As a result, we used "intended beneficiary" (a term used in the 2nd Restatement) in combination with "third party beneficiary." After limiting the results to the past ten years (2004-2014), we came up with the 1,406 cases used in this study.

61 We began with the terms "third party beneficiaries", "network contract", "contractual network", "third party creditor beneficiary", "business network", "intended beneficiary", and "network." Not surprisingly, "network" proved to be used in too many cases that were of no interest.

62 The vast majority of cases used the Second Restatement's distinctions between intended and incidental beneficiaries found in section 302(1), albeit in varying ways. We made a number of decisions in the coding process that may have colored the resulting data and subsequently, the outcomes of our tests. First, we defined a business network as "a number of independent firms that enter a pattern of interrelated contracts that are designed to confer on the parties many of the benefits of coordination that are achievable through vertical integration in a single firm." Second, we assumed that if a case decision did not provide any indication that the group or class of the third party claimant was explicitly referred to or identified in the language of the contract, then such references were also absent in the actual language of the contract. Any explicit mention of the third-party in a contract would be an important detail in the courts' analysis (it is often the deciding factor) and therefore, would presumably be mentioned in the decision. Third, any loss that was non-speculative, financially substantial, or threatened the ability for a firm to continue business was considered "substantial." 


\subsubsection{Data and Analysis}

Although the small sample size and the judgment required to code the cases accurately give reasons to avoid broad conclusions, nonetheless we find the results broadly consistent with all three hypothesis. Even though the random sample yielded only 34 usable cases, there were enough examples in each of the two main categories (whether the court found third party status or not) to give us some statistically significant data.

As Table 1 shows, courts found in favor of the third-party claimant in twelve of the thirty-four cases. In eleven of the sixteen cases (69 percent) where the third-party claimant was a member of a class or group explicitly referred to or identified in the disputed contract, the court found third-party beneficiary liability. In ten of the twenty-three cases (43 per cent) where the third-party plaintiff claimed substantial losses, the court imposed third-party liability. Finally, in six of the nine cases $(67 \%)$ where the parties were members of a business network, the court found third-party liability. ${ }^{63}$ On the basis of these results we were able to test all three hypotheses.

Hypothesis 1: Intent to benefit a third party is found when the contract members can anticipate and probably price the cost of serving particular third parties. In eleven of the twelve randomly selected cases where the court was willing to allow a third party claim to proceed, the court found evidence of "circumstances" (including references in the contract itself) sufficient to support the presumption that the risk of increased liability for defective performance was appreciated by the promisor and (presumably) priced into the contract. $^{64}$ These courts found that, taken together, the contract and the circumstances justified a third party claim when the contract was essentially a pass through to an identified third party, ${ }^{65}$ or when the third party was "a member of a class referred to and identified in [the contract]."66 On the other hand, where summary judgment was granted against the third-party claimant, the evidence revealed that the third-party interest in the contract

63 A few other findings may be of interest. The "average" year in which the decisions were made is almost identical between the two groups (2009.7 and 2009.9), suggesting that there is little if any temporal trend in the courts towards finding or not finding for the third-party claimant. Of the eight cases where the parties were part of a business network, six were working together as part of a project management group (owner-contractor-sub), and two were part of an insurance network.

64 See e.g., Holmes v. Federal Ins. Co. 820 NE 2d 526 (Ill. App. 2004). In Holmes, the court found a reasonable question of fact regarding the third-party status of the plaintiff based on evidence that the plaintiff was asked to sign the contract, and that the contract had details about the plaintiff's entitlements, salary, and benefits.

65 Koken v. Legion Insurance Co., 831 A. 2d 1196 (Pa. 2004) (policy holder is a third-party beneficiary of the contract between initial "front man" insurer and reinsurer who held all the risk).

66 Hawaii Stevedores, Inc., v. HT\&T Co., 363 F. Supp. 2d 1253 (D. Haw. 2005). 
Table 1. Descriptive statistics

\begin{tabular}{lllr}
\hline & $\begin{array}{l}\text { Number of } \\
\text { Cases in Category }\end{array}$ & $\begin{array}{l}\text { Number Where } \\
\text { Court Found } \\
\text { TPB (Percent) }\end{array}$ & $\begin{array}{l}\text { Number Where } \\
\text { Court Did Not } \\
\text { Find TPB (Percent) }\end{array}$ \\
\hline Group Identified (H1) & 16 & $11(69)$ & $5(31)$ \\
Substantial Damages $(\mathrm{H} 2)$ & 23 & $10(43)$ & $12(57)$ \\
Business Network (H3) & 9 & $6(67)$ & $3(33)$ \\
Totals & $\mathbf{3 4}$ & $\mathbf{1 2}(\mathbf{3 5})$ & $\mathbf{2 2}(\mathbf{6 5})$ \\
\hline
\end{tabular}

either (i) arose after the contact was written, ${ }^{67}$ or (ii) indicated in its terms that no third-party rights were to be recognized, ${ }^{68}$ or, (iii) most frequently, showed that the third parties were part of a large and undefined group at the time of contract. ${ }^{69}$

Hypothesis 2: Courts grant third party claims more frequently when the beneficiary attaches substantial value to the contract performance. This hypothesis rests on our analysis of the strategic complement and substitute contexts, in which the plaintiff agents have invested in the network project but the defendant agents are alleged to have defected. We caution that the evidence to support this hypothesis relies on the judgment required in hand coding the cases, but nevertheless the cases are broadly consistent with the hypothesis. In ten of the twelve cases in which the court allowed a third party claim to proceed, the plaintiff's claim was supported by allegations of substantial losses. These courts authorize the third party to go forward with its offer of proof when (i) the plaintiff had considerable out of pocket financial losses owing to the defective performance of the promisor, ${ }^{70}$ or (ii) the breach by the promisor threatened the on-going business enterprise of the third party. ${ }^{71}$ In contrast, third party

67 Bariteau v. PNC Financial Services Group, Inc., 285 Fed. Appx. 218 (2008); Cloud Nine v.Whaley, 650 F. Supp. 2d 789 (E.D. Tenn. 2009).

68 Joseph v. Hospital Service District No 2 of the Parish of St. Mary, 939 S0. 2 d 1206 (La. 2006) (contract with service provided specifies no employer/employee relationship and thus physicians are not third-party beneficiaries); Register.Com, Inc., v. Verio, Inc., 356 F. 3d 393 (2d Cir. 2004) (express "no third party beneficiary" clause in SSO contract).

69 Ward v. Glover, M.D., 206 S.W. 3d 17 (Tenn. 2006) (patient is not an intended beneficiary of the contract between hospital and medical director requiring him to ensure that proper procedures were followed); Jenkins v. Best, M.D., 250 S.W. 3d 680 (Ky. 2007) (same).

70 A.E.I Music Network, Inc., v. Business Computers, Inc., 290 F. 3d 952 (7th Cir. 2002) (subcontractor unpaid for $\$ 159,000$ owing to failure of owner to require general contractor to post a bond).

71 In re Innovatio IP Ventures, LLC Patent Litig., 2013 WL 427167 (N.D. Ill. February 4, 2013) (businesses using patented processes can sue for "all foreseeable damages" if contractual obligation to extend licenses on RAND terms is not met); Samsung v. Apple, 2012 WL 1672493 (N.D. Cal.) (same). 
claims are dismissed on summary judgment when the plaintiff's losses are speculative, ${ }^{72}$ based on "future earnings, mental anguish, grief and anxiety," 73 or, most frequently, when the financial losses were de minimus. ${ }^{74}$

Hypothesis 3: Courts grant claims by third party members of a business network more frequently than claims by non-network members. Hypothesis 3 is based on the premise that when network members are an identified class of interested parties in the bilateral contracts of some network members, class size is largely fixed ex ante, so that the problem of excess demand is small. ${ }^{75}$ In addition to the size factor, network membership has several key internalizing features. First, the relational bonds that forge the membership create a natural affinity group that is readily identifiable ex ante and thus more likely to be priced in the bilateral contract. Second, the relation-specific investment in the network undertaken by all members implies that the third party will generally attach substantial value to the promised performance. Finally, the plaintiff's value in the performance is also a function of her obligation to confer subsequent benefits on the promisor. In such a case, she would claim the right to the performance only when her value exceeded the later benefit. In combination, the size factor and these network conditions are consistent with the data. Courts recognized the possibility of third-party rights in 50 percent of the network cases but only endorsed the third party's claim in 13 percent of the non-network cases. (see Table 2, below).

The data also show that the success rate of third party claims is not evenly distributed across different networks. The number of cases for any given network in our sample is too small to permit firm conclusions but the results permit some tentative observations. Suits by members of a standard setting network seeking damages caused by a refusal of a patent holder to license the patent on RAND terms appear to have the highest rate of success. ${ }^{76}$ This result

72 Textile Rubber and Chemical Co., Inc., v. Thermo-Flex Technologies, Inc., 308 Ga. App. 89 (Ga. App. 2011).

73 Joseph v. Hospital Service Dist. No. 2 of Parish of St. Mary, 939 So. 2d 1206 (La. 2006).

74 Albe v. City of New Orleans, 97 So. 3d 583 (2012) (plaintiff issued a traffic citation as a result of defective cameras installed by defendant is not a third-party beneficiary of contract between the city and the installer).

75 See e.g., Sovereign Bank v. BJs Wholesale Club, Inc., 533 F. 3d 162 (3d Cir. 2008) and cases cited in notes- to-infra.

76 In re Incovatio IP Ventures, 2013 WL 427167 (N.D. Ill.) (promises for RAND licenses "plainly contemplate benefitting users."); Apple, Inc. v. Samsung Electronics Co., Ltd., 2012 WL 1672493 (N.D.CAL.) (same); Microsoft Corp. v. Motorola, Inc., 696 F. 3d 872 (9th Cir. 2012) (same). But see Register.com v. Verico, Inc., 356 F. 3d 393 (2d. Cir. 2004) (express term in SSO contract with defendant providing that " $[\mathrm{t}]$ his agreement shall not be construed to create any obligation. ...to any non-party to this Agreement....”). 
may be attributable to the complementarity among the bilateral contracts between members of the network and the standard setting organization.

Similar successes by third parties occur in disputes between subcontractors and project owners arising out of either non-payment by the owner or defective performances by the subcontractor. In each case, the plaintiffs were relying on bilateral contracts between the owner and the general contractor and the general contractor and the sub-contractors respectively. ${ }^{77}$ For example, in A.E.I Music Network, Inc., v. Business Computers, Inc., ${ }^{78}$ the court held that an unpaid subcontractor was a third-party beneficiary, as a matter of law, of a contract between the owner and general contractor that required the general contractor to post a bond sufficient to assure payment to the subcontractors. Writing for the court, Judge Posner held that when the necessary conditions are satisfied, permitting third-party beneficiary suits is "consistent with freedom of contract and also reduces transactions costs by conferring rights. . on persons without requiring them to become involved in the contractual negotiations."79 Construction networks such as these are commonly circumscribed and thus the intended extension of benefits to non-contracting network members are clear. ${ }^{80}$

Franchise networks are more attenuated and the litigation among the members (and potential entrants) is more varied. Cases in the sample involving a third party suit against a party to the master agreement between the franchisor and its franchisees generally succeeded. This evidence is consistent with several earlier cases involving franchisees. In Hawkinson $v$. Bennett, ${ }^{81}$ for example, the court held that sales franchisees were, as a matter of law, third-party beneficiaries of the contract between the franchisor and the master franchisee. Similarly, in Int'l Pizza Hut Franchise Holders Ass'n, Inc., v. Supreme Pizza, Inc., ${ }^{82}$ the court held that the franchisee association was a third-party beneficiary of the bilateral contract between the franchisor and an individual franchisee and so was

77 Aetna Cas. \& Sur. Co. v. Fireguard Corp., 249 Va. 209 (1995); A.E.I Music Network,

Inc., v. Business Computers, Inc., 290 F. 3d 952 (7th Cir. 2002); Guardsman Elevator Co., Inc., v. United States, 50 Fed. Cl. 577 (2001).

78290 F. 3d 952 (2002).

79 Id. at 955.

80 The recent case of Burch v. Superior Court, 223 Cal. App. 4th 1411 (2014) raises an analogous issue of third-party liability in the construction context. The plaintiff purchaser alleged that she was a third-party beneficiary of the contract between the developer and the general contractor. The appellate court supported the trial court, which found that "there was a triable issue of fact as to whether the plaintiff was an intended beneficiary of the construction contract, and therefore denied summary adjudication of the breach of contract count."

81265 Kan. 5645 (1998).

82464 F. Supp. 65 (D. Kan. 1998). 
Table 2. Statistical hypothesis tests (t-tests)

\begin{tabular}{llll}
\hline & $\begin{array}{l}\text { Percent Where } \\
\text { Court Found } \\
\text { TPB (Number) }\end{array}$ & $\begin{array}{l}\text { Percent Where } \\
\text { Court Did Not } \\
\text { Find TPB (Number) }\end{array}$ & $\begin{array}{l}\text { P-value of } \\
\text { Difference in } \\
\text { Proportions (t-stat) }\end{array}$ \\
\hline Group Identified (H1) & $91.67(11 / 12)$ & $22.73(5 / 22)$ & $0.000(6)$ \\
Substantial Damages (H2) & $83.33(10 / 12)$ & $59.09(13 / 22)$ & $0.13(1.56)$ \\
Business Network (H3) & $50.00(6 / 12)$ & $13.64(3 / 22)$ & $0.046(2.16)$ \\
\hline
\end{tabular}

entitled to bring suit against the individual franchisee for refusing to join the association as the contract required. ${ }^{83}$ Finally, in the case of credit card networks, the courts are split on the right of issuing banks to recover against merchants whose failure to protect customer information permitted fraudulent use of credit cards. ${ }^{84}$

\subsubsection{Statistical Hypothesis Test}

Using the descriptive data presented in Table 1, we ran a series of t-tests on each of the data-points that address our three hypotheses (see Table 2, above). ${ }^{85}$

The $\mathrm{t}$-tests in Table 2 support the three hypotheses. Cases in which the court found in favor of the third party were much more likely (about 70 percentage points more likely) to have claimants who were part of a group or class that was explicitly mentioned in the contract (supporting Hypothesis 1). This difference is statistically significant at the 0.000 level, meaning that we can be almost 100 percent confident that the difference between the two groups of cases is not due to chance. Likewise, cases in which the court found in favor of the third-party claimant were also much more likely (about 40 percentage points) to involve parties that were part of a business network (supporting Hypothesis 3). This difference is also statistically significant, although the p-value of 0.046

83 Id. at $66-67$.

84 See, e.g., Sovereign Bank, 533 F.3d at 164 (granting issuer the right to sue merchant for nonperformance of contract with acquirer). But see In re TJX Co., supra note 16 (concerning a similar fact pattern, but reaching a different result on the merits); In re Heartland Payment Systems, Inc. Customer Data Sec. Breach Litig., 834 F. Supp. 2d 566 (S.D. Tex. 2011) (same).

85 A t-test is essentially a comparison of means that tells us how confident we can be that two groups of data are different. A t-test that produces a low p-value suggests that we can be confident that the two groups are statistically distinct. Alternatively, higher p-values represent lower levels of confidence. The cutoff point in the social sciences is generally a p-value of 0.05 , although this specific standard is essentially arbitrary. It is important to note that, given our data generating process (non-experimental), a statistically significant t-test does not indicate any causal relationship; it only tells us that the means of the two groups of data are statistically different from each other. Also, t-tests, like many statistical hypothesis tests, assume that the pattern of the data follows a particular distribution. We do not know the underlying distribution of the data, so we are making a (weak) assumption by running these tests . 
indicates that we are about 95 percent confident that this difference is not due to chance. While cases where the court found in favor of third-party claimants were slightly more likely to feature claims for substantial damages (about 25 percentage points), we can only be 87 percent confident that this difference is not due to chance (which does not strongly support Hypothesis 2). ${ }^{86}$

Given the results of these tests, one might be tempted to posit some kind of causal relationship. We remain very skeptical of any such suggestion, however, because we do not employ any reliable identification strategy for our models. We considered running a more sophisticated set of tests, such as a probit analysis controlling for additional variables, but we felt that doing so might lead some to make inferences that lie beyond the limitations of our dataset. Such tests can theoretically provide researchers with unbiased measurements of causal impact, but only when a set of strong assumptions is met. Our data, and subsequently, our statistical models do not meet those assumptions. Thus, we are content to say only what the data indicate: that there are statistically significant correlations in our data.

\section{NORMATIVE IMPLICATIONS: WHAT SHOULD COURTS DO?}

In this section, we evaluate what courts should do in deciding third party claims in contrast with what our analysis in Section V shows they actually do. In our view, the courts are too restrictive. Our case sample shows that some third parties do prevail in circumstances that appear to advance contract member goals but other third parties are denied relief (either in whole or in part) in cases where our normative criterion suggests they should be allowed to proceed against the promisor.

\subsection{Efficient Remedies ${ }^{87}$}

Third-party plaintiffs who sue in connection with strategic substitute networks ordinarily cannot establish an expectation interest remedy. ${ }^{88}$ In these cases, the nature of the project the network was to pursue often is ill defined at the outset, and there is no final project. A plaintiff, however, sometimes can prove costs

86 Sorting appellate cases by the size of damages is difficult because cases litigated to appellate courts commonly involve substantial damages. Thus, our $11 \%$ confidence level may suggest a real effect.

87 We note again that we measure efficiency here as what best advances network goals. We cannot definitely say what remedies would increase welfare all in all.

88 A plaintiff in connection with a strategic complements case also may have this problem when a part of an agent's performance is informative respecting the profitability of other agents' performances but the network project does not come to fruition. 
incurred in reliance on network member promises. Hence, in these cases the remedy issue is simple: if an agent is found to be a beneficiary member, she should be permitted to recover verifiable reliance costs. ${ }^{89}$

Remedy issues in the strategic complements case are more complex. ${ }^{90}$ To analyze them, refer again to the model in Section 4.1. The performing party A should perform when total benefits exceed total costs: $y_{B}+y_{P}>c$, where $\mathrm{c}$ is the performing party A's realized cost, the first left hand term is the third party's benefit and the second term is the promisee's benefit. The performing party, however, prefers to breach when $\mathrm{z}<\mathrm{c}$, where $\mathrm{z}$ is the price $\mathrm{P}$ pays him to perform. For example, let $\mathrm{z}$ be the price a service provider agrees to pay to a hospital and $\mathrm{c}$ be the realized cost of serving a potential patient. If $\mathrm{z}<\mathrm{c}$, the hospital would prefer to refuse, or to truncate, service. A potential beneficiary's - the disserved patient's—-best response would be to sue for his expectation, $\mathrm{y}_{\mathrm{B}}$, whenever it is positive because he does not pay a price to A. ${ }^{91}$

Under current third-party beneficiary doctrine, ex post efficiency can be difficult to achieve. In some cases, courts have permitted the beneficiary to recover costs incurred but not her expectation. ${ }^{92}$ Denoting B's costs as $r$, A thus may breach when $\mathrm{c}-\mathrm{z}>\mathrm{r}$ : the net loss from performing - the left hand side-is greater than the damages - the right hand side. Because rationality implies that $y_{B}>r$ (the beneficiary expects to make a gain), awarding the beneficiary only reliance implies that the performing party breaches too often. This analysis suggests that courts should be willing to permit the beneficiary to recover her expectancy. But allowing the beneficiary to recover full expectation damages may in some cases induce the promisor to perform inefficiently. As the analysis below shows, the efficient remedy in strategic complement cases

89 Section 4.3 above sets out criteria that courts should use when deciding whether a third party is a beneficiary member. A standard result in remedy theory is that the reliance remedy creates an incentive for the promisee to over-rely in order to compel the promisor to perform even when performance would be inefficient. This argument exhibits the superiority of the expectation remedy when a court can measure it. The choice here, however, is between a reliance remedy and no remedy at all. The text above argues that contract members would prefer reliance to zero.

90 In the analysis that follows, we assume that it would be ex ante efficient for the network to serve the potential beneficiary member; that is, the beneficiary is in the $\mathrm{q}^{*}-\mathrm{q}^{\mathrm{a}}$ interval.

91 B may have incurred reliance costs or paid the promisee but those expenses are sunk when B decides whether to sue.

92 The denial of expectancy recoveries has occurred most frequently in cases where the contracting parties have agreed to modify their contractual obligations ex post. In these cases, the beneficiary has been permitted to recover reliance expenditures prior to the modification but has been denied any claim for expectation damages. See Restatement (Second) of Contracts $\$ 311$ and text accompanying notes 109-11 infra. 
requires a court to reduce the award of expectation damages by the amount of the price paid to the promisor by the promisee.

If the law were to protect the beneficiary member's expectation, A would perform when $\mathrm{c}-\mathrm{z}<\mathrm{y}_{\mathrm{B}}$; that is, when performance would be efficient. ${ }^{93}$ Because $\mathrm{z}$ is positive, however, $\mathrm{A}$ also may perform when $\mathrm{c}>\mathrm{y}_{\mathrm{B}}$; that is, when breach would be efficient. The intuition is that $\mathrm{P}$, the paying party, subsidizes B's benefit by paying the price to A. Therefore, the benefit that the contract members intended to confer on $\mathrm{B}$ at the price $\mathrm{z}$ can turn out to be worth less to $B$ than the costs of serving her. Performance would nevertheless be efficient if total benefits exceed total costs. There may be cases, however, in which the promisee's gain is too small to overcome the inefficiency in the A/B relation. In these cases, A would perform when performance would be inefficient all in all.

The inefficient performance concern would vanish if B could recover $y_{B}$, her benefit, less the sum $\mathrm{t}$, where $0 \leq \mathrm{t}<\infty$. Then A would perform when her loss from performance is less than the (modified) damages she has to pay, or when

$$
\mathrm{c}-\mathrm{z}<\mathrm{y}_{\mathrm{B}}-\mathrm{t}
$$

Otherwise, A breaches. Now set $t=z$. Then A performs when $c<y_{B}$ and breaches otherwise. To see why this solution works, setting $t=z$, and subtracting $\mathrm{t}$ from B's gross expectation, requires $\mathrm{B}$ in effect to pay the price of the performance she prefers. $^{94}$

To summarize, in the strategic complement and substitute cases the potential beneficiary member should be permitted to recover his reliance loss. The existence of those losses is consistent with an ex ante intention of contract members to benefit such plaintiffs. In the strategic complements case, the third party should be permitted to sue for her expectation, when courts can recover it, less the price the network members created for the relevant performance. This will help to ensure that the network is at its optimal size, where it serves only those potential parties whose gains would exceed the costs of serving them.

\subsection{Vague and Fluid Beneficiary Classes}

As our analysis of the cases shows, courts are reluctant to grant relief to a potential beneficiary member who belongs to a vague or a fluid class. A class is vague when the contract members know the class's approximate size but cannot identify many members in advance. ${ }^{95}$ As an example, $\mathrm{P}$ may want to

93 Note: $c<y_{B}$ implies that total benefits exceed total costs because $y_{P}$ is bounded from below by zero.

94 The price $\mathrm{z}$ is verifiable because it is a contract term.

95 As Section 4 notes, this is a common feature of networks: an agent at a particular network node knows her own degree but seldom knows the degree of agents at other nodes. 
attract a particular group of consumers and hires A, an advertising specialist, to offer certain deals to consumers in the group if they patronize $P$. The consumers would benefit from receiving the benefits the $\mathrm{P} / \mathrm{A}$ contract directs. The contract parties - $\mathrm{P}$ and A-may be able to predict about how many consumers will show up but cannot know in advance who they are. A beneficiary class is fluid when agents enter and leave through time. The class size may stay approximately constant but again $\mathrm{P}$, and perhaps $\mathrm{A}$ at the start, cannot identify every member.

Excluding liability in vague and fluid class cases is inefficient when class size does not exceed $\mathrm{q}^{*}$; then the expected cost of serving class members does not exceed the expected benefit to the contract members. Hence, the members ex ante prefer courts later to confer beneficiary status on third parties within the expected class. The failure of courts to implement this intention rests on a mistake. Courts appear to ask whether the contract members can identify $a$ particular possible beneficiary and price the cost of serving her. The right question is whether the contract members can identify a potential beneficiary class that is sufficiently distinct to price serving it. The failure of courts to ask the right question materially decreases the law's ability to facilitate network formation and function because vague and fluid networks-networks characterized by imperfect information-are common.

Two novel remedy issues would arise, however, if contract members can be liable to potential beneficiaries in vague or fluid classes. Regarding the first, denote the total class benefit $\pi_{B}=\sum_{1}^{B} y_{b_{i}}$. Now let a particular member, say $\mathrm{B}_{11}$, sue a contract member. The issue is how to assess this plaintiff's damages. There are three possible rules: (a) Symmetry: each plaintiff is assumed to be identical so if the class has $B$ members, each plaintiff is awarded $d_{i}=(1 / B) \pi_{B}$. This rule seems plausible when potential class members have a relatively common identity but may amount to no liability. The first plaintiff would have to establish B and $\pi_{\mathrm{B}}$ but could recover only $\mathrm{d}_{\mathrm{i}}$. If it is costly to prove the total benefit and the total damages are relatively small, a potential first plaintiff may find suit not worthwhile. But if the symmetry assumption is plausible, then no plaintiff would find suit worthwhile and the equilibrium result is no liability. (b) Individuation: each plaintiff must prove only her own expectation. In contrast, to symmetry, under the individuation rule a plaintiff need only establish her own harm, and the basis for liability. Contract members, however, may object that they could not identify particular members in advance and so could not price serving each of them. This response is unpersuasive. The contract members' best response to rule (b) would be to make a symmetry assumption for themselves: because class members ex ante appear identical to contract members, the contract members' best assumption would be that each class member would suffer a loss of $(1 / \mathrm{B}) \pi_{\mathrm{B}}$ on breach. Hence, if every beneficiary sues, the 
contract members would face an expected liability of $\mathrm{B}(1 / \mathrm{B}) \pi_{\mathrm{B}}=\pi_{\mathrm{B}}$. This is the right amount so individuation actually reduces to a symmetry rule with a reverse burden of proof. Under this rule, a plaintiff could recover her expectation unless a contract member could show that she did not incur a loss. (c) No liability: contract members are only liable to third parties whom they can identify in advance.

Rule (c) is inefficient for the reasons given above and rule (a) in practice would reduce to rule (c). Rule (b) is efficient, and under it a plaintiff could recover her expectation. In short, every remedy issue yields the same answer: when contract members expect to benefit from serving a beneficiary member class, its members should recover their expectation less the price the network members created for the relevant performance. We also recall that some cases enforce third party claims but create an interpretive presumption that contract members do not intend to benefit non-parties. The analysis here shows that there is no economic basis for this presumption, and that courts that follow it unnecessarily hinder network formation.

Regarding the second remedy issue, the danger of excess demand apparently is increasing in the vagueness or fluidity of the beneficiary class. In some of these contexts, the contract members apparently could give effective notice, however. For example, advertisements or other public notices may recite "Service is limited" or "first come first served" or the like. When such notices likely would be effective, the usual default should be reversed: that is, contract members should be liable when they could have given effective notice but did not. When notice apparently would be ineffective, courts should stay with the current no remedy default. Potential beneficiaries then must prove that it would be ex ante optimal for network members to serve them.

\section{CONCLUSION}

Third-party beneficiary law occupies an arcane section of the Contracts field. The subject usually is treated in the last chapter of the typical contracts casebook (Scott \& Kraus 2013); the books illustrate the subject with nineteenth and early twentieth century cases; and the subject is seldom taught. ${ }^{96}$ It has attracted little scholarly attention. This neglect no longer is justifiable. Doctrines that the early cases developed are outmoded because the transactions those cases involved did not create spillover effects. For example, P asked

96 Ferriell (2009), a standard text for students, recites: “Depending on whether your [the students'] Contracts course is four, five, or six credit hours, it might also cover the rules governing how a contract might affect third parties: those who were not directly involved in its formation.... Some Contracts courses, particularly those that do not last the entire year, never reach these topics." 
A to pay a debt $\mathrm{P}$ owes to $\mathrm{B} .{ }^{97}$ The promisor A's actions to perform or to breach could affect only $\mathrm{P}$ and $\mathrm{B}$. As the extensive case analyses above show, however, the many-the very many-modern cases commonly involve transactions that create externalities. These cases are peopled with network agents: potential network members who claim not to receive what they expected or who incurred reliance losses, and defendant network members who are accused of unjustifiably excluding potential members or of not pursuing the network project.

Today's doctrine instructs courts to view the modern cases through a nineteenth-century lens. The legal question is whether the contract parties intended to confer a benefit on the plaintiff. The courts' focus on intent yields some sound results: courts enforce contracts that expressly say that third-party benefits are intended, or are not. When a contract is unclear, courts are more likely to honor third party claims when the contract parties probably could price them, when the contract parties can identify potential network members in advance and when a potential third-party beneficiary has incurred material reliance costs. Plaintiffs in these categories could hold a plausible belief that the relevant network would serve them because it would be ex ante profitable for the network to do so.

We argue here that courts should ask a different question, however: whether it would be ex ante profitable for the network contracting members to serve the potential beneficiary class to which the plaintiff belongs. A consistent judicial pursuit of this question would facilitate optimal network formation and function. Asking the wrong question unsurprisingly sometimes yields the wrong answer. Thus, some courts construe contracts with a strong presumption that no third-party benefits were intended, and they seldom honor third party claims when the contract network members can identify the class to which the plaintiff potential beneficiary belongs, but cannot identify particular members of that class in advance. These results are inconsistent with the criterion of network welfare.

It may be tempting to conclude that courts are relatively incapable of undertaking the rather more complex analysis that we propose here. Indeed, an extreme example of this view argues for a clear statement rule: there should be no third-party liability unless the contract "expressly" so recites. The premise for such a clear statement rule would be that the network parties do not want third parties to win in the ordinary case, so third parties lose unless network parties really want them to recover in the case at bar. To the contrary, our analysis shows that such a premise would be groundless: sometimes network parties ex 
ante would want liability and sometimes not. Hence, there is no good reason for biasing the interpretive result against liability in general. Rather, the usual contract interpretive principle should obtain-implement the parties' intentionsas recovered with the aid of our analysis.

Nevertheless, our positive and normative conclusions are tentatively held for at least three reasons. First, lawyers have largely ignored the subject so what courts do and what courts are capable of doing in network contexts are largely unexplored issues. There is not much institutional wisdom to exploit. Second, the economic literature asks basic questions regarding network stability, how agents develop and communicate information in various network types and what equilibria the network agents are likely to reach. The answers to these questions seldom are helpful to lawyers. We are concerned with the agreements network members sometimes reach and the consequent issues of breach and remedy. Hence, the economic literature to date offers less wisdom here than it does in other contexts. Third, our normative criterion is partial: legal rules that increase network member welfare will not always increase social welfare. It is an open question just how wide the actual divergence is between local and global efficiency.

Despite these caveats, we conclude with two claims. First, the issues raised by third-party beneficiary suits in connection with business networks deserve a more prominent place in doctrinal and in law and economics scholarship. The demand for an increased scholarly focus on the nature and extent of legal liability in network contexts is justified by the subject's practical significance, its normative importance and its intellectual interest. Second, we believe that courts should interpret the reigning legal standard of intent to benefit third parties in terms that promote the formation and performance of contractual networks. This normative criterion is more likely to survive a global regulatory treatment than is the skeptical posture of current law.

\section{REFERENCES}

Axelrod, Robert. 1984. The Evolution of Cooperation. New York: Basic Books. Bramoulle, Yann et al. 2014. Strategic Interaction and Networks. 104 American Econ. Rev. 898-930.

Charness, Gary et al. 2014. Experimental Games on Networks: Underpinnings of Behavior and Equilibrium Selection. 82 Econometrica 1615-1670.

Correani, et al. 2014. R\&D Cooperation in Regular Networks with Endogenous Absorptive Capacity. 13 Rev. Network Econ. 191-226.

Dawid, Herbert \& Tim Hellmann. 2014. The Evolution of R\&D Networks. 105 J. Econ. Behavior \& Organ. 158-172. 
Eisenberg, Melvin A. 1992. Third Party Beneficiaries. 92 Colum. L. Rev. 13581430.

Francesco, Feri \& Paolo Pin. 2014. "The effect of externalities aggregation on network games outcomes." SSRN \# 2474079.

Ferrari, Chiara. 2010. The Italian "Network Contract": A New Tool for the Growth of Enterprises Within the Framework of the "Small Business Act.” 16 Columbia J. Eur. L. 77-84.

Ferriell, Jeff. 2009. Understanding Contracts. 2nd Edition. New Providence NJ: Mathew Bender \& Co.

Galeotti, Andrea et al. 2010. Network Games, 77 Rev. Econ. Studies 218-244.

Hattori, Keisuke \& Lin Ming Hsin. 2014. Complementary Alliances in Composite Goods Markets with Network Structure. 82 The Manchester School 33-51.

Jackson, Matthew O. 2014. Networks in the Understanding of Economic Behaviors. 28 J. Econ. Perspectives 3-22.

Kraus, Jody S. \& Robert E Scott. 2009. Contractual Design and the Nature of Contractual Intent. 84 New York University L. Rev. 1023-1104.

Powell, Walter W. 1990. Neither Markets Nor Hierarchy: Network Forms of Organization. 12 Research in Organizational Behavior 295-296, 303-304.

- 1996. Inter-Organizational Collaboration in the Biotechnology Industry. 152 J. Instit. \& Theoret. Econ. 197-215.

Powell, Walter W., Kenneth Koput \& Laurel Smith-Doerr. 1996. Interorganizational Collaboration and the Locus of Innovation: Networks of Learning in Biotechnology. 41 Admin. Sci. Quart. 116-145.

Rogerson, William P. 1984. Efficient Reliance and Damage Measures for Breach of Contract. 15 Rand J. Econ. 39-53.

Schwartz, Alan \& Robert E Scott. 2007. Precontractual Liability and Preliminary Agreements. 120 Harvard L. Rev. 661-707.

Scotchmer, Susanne. 2004. Innovation and Incentives. Cambridge: MIT Press.

Scott, Robert E. \& Jody S Kraus. 2013. Contract Law and Theory. 5th Edition. New Providence NJ: Mathew Bender \& Co.

Teubner, Gunther \& Hugh Collins. 2011. Networks as Connected Contracts. London: Hart Publishing Co.

Waters, Anthony Jon. 1985. The Property in the Promise: A Study of the Third Party Beneficiary Rule. 98 Harvard L. Rev. 1109-2010. 